\title{
Open Letter to Ma José Lobo on the Occasion of her Retirement
}

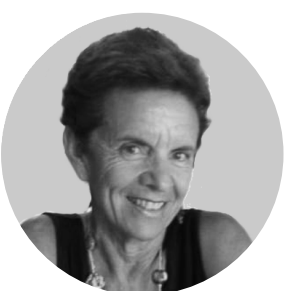

BEATRIZ CABALLERO DE RODAS

UNIVERSITAT AUTÒNOMA DE BARCELONA

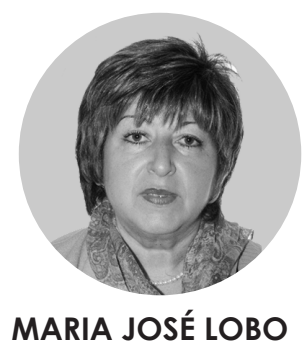

schools and their realities (at all levels!). Your ability to transmit this knowledge. Your common sense. Your realistic and yet ambitious objectives. Your tireless dedication. Your involvement in EDUCATION with capital letters. Your respect for your students and colleagues. Your creativity. Your sense of humour...

Moreover -and this is perhaps something you yourself are unaware of, María José- you master a very difficult art, the art of providing students with constructive and effective feedback on their teaching performances. You have a sincere, clear and yet tactful way of helping students discover their own strengths and weaknesses, while opening doors for them to find solutions. This is something I have witnessed many times during our school visits to Richmond.

I have often heard students say: 'When I am a teacher, I want to be like María José Lobo'. I understand them. I think that if I started my professional career again, I would also say: 'I want to be like María José Lobo'.

It has been a great pleasure to work with you, María José. You are also a wonderful friend and I appreciate your friendship more than I can say.

Thank you very much for everything you have given us and enjoy the 'New Life' that you have just started!

Bellaterra, 22 November 2019 